\title{
Obituary
}

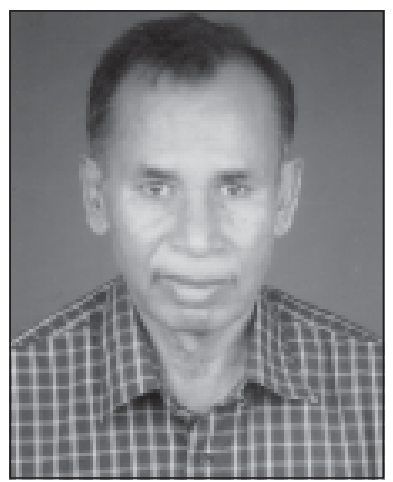

\section{Professor Dwijendra Chandra Dey}

(1938-2010)

We deeply mourn at the death of Prof Dwijendra Chandra Dey, a nationally reputed Professor of Anatomy.

Prof Dwijendra Chandra Dey was born in 22.4.1938. He passed his SSC in 1954 and HSC in 1957 from Dhaka Board. He obtained his MBBS degree from Dhaka Medical College in 1963 and M Phil degree in Anatomy from IPGMR in 1972.

Prof Dwijendra Chandra Dey served in different medical colleges during his life span. He worked as the Head of the Department of Anatomy in Sir Salimullah Medical College, Rangpur Medical College, Khulna Medical College and Mymensingh Medical College. It can be mentioned that he was the first Head of of the Department of Anatomy, when Mitford LMF School was converted into Sir Salimullah Medical College in 1972. He retired from Government service in 1995 from Mymensingh Medical College. After his retirement, Prof Dwijendra Chandra Dey served in Community Based Medical College and Pioneer Dental College. East West Medical College was his last working place.

Prof Dwijendra Chandra Dey was an inborn teacher. He taught the medical students with utmost sincerity and dedication. He had keen interest in the subject and to its reflection he wrote a guide book for undergraduate and post-graduate medical students. The book at that time benefited many students.

Prof Dwijendra Chandra Dey taught Anatomy for long 43 years. He was legendary teacher. He was honest and bore an amicable character.

His hobby was reading. He advised the young anatomists "to acquire knowledge in his/her own subject".

Prof Dwijendra Chandra Dey succumbed to death at the age of 72 years in BIRDEM hospital after suffering from prolonged illness.

Anatomical Society of Bangladesh expresses most profound grief and sorrow at this irreplaceable loss and extends their deepest condolence to the bereaved family. 